\title{
Discovery, cloning and characterisation of proline specific prolyl endopeptidase, a gluten degrading thermo-stable enzyme from Sphaerobacter thermophiles
}

Shetty, Radhakrishna; Vestergaard, Mike; Jessen, Flemming; Hägglund, Per; Knorr, Verena; Koehler, Peter; Prakash, H.S.; Hobley, Timothy John

\section{Published in:}

Enzyme and Microbial Technology

Link to article, DOI:

10.1016/j.enzmictec.2017.08.002

Publication date:

2017

Document Version

Peer reviewed version

Link back to DTU Orbit

Citation $(A P A)$ :

Shetty, R., Vestergaard, M., Jessen, F., Hägglund, P., Knorr, V., Koehler, P., Prakash, H. S., \& Hobley, T. J. (2017). Discovery, cloning and characterisation of proline specific prolyl endopeptidase, a gluten degrading thermo-stable enzyme from Sphaerobacter thermophiles. Enzyme and Microbial Technology, 107, 57-63. https://doi.org/10.1016/j.enzmictec.2017.08.002

\section{General rights}

Copyright and moral rights for the publications made accessible in the public portal are retained by the authors and/or other copyright owners and it is a condition of accessing publications that users recognise and abide by the legal requirements associated with these rights.

- Users may download and print one copy of any publication from the public portal for the purpose of private study or research.

- You may not further distribute the material or use it for any profit-making activity or commercial gain

- You may freely distribute the URL identifying the publication in the public portal 


\section{Accepted Manuscript}

Title: Discovery, cloning and characterisation of proline specific prolyl endopeptidase, a gluten degrading thermo-stable enzyme from Sphaerobacter thermophiles

Authors: Radhakrishna Shetty, Mike Vestergaard, Flemming Jessen, Per Hägglund, Verena Knorr, Peter Koehler, H.S.

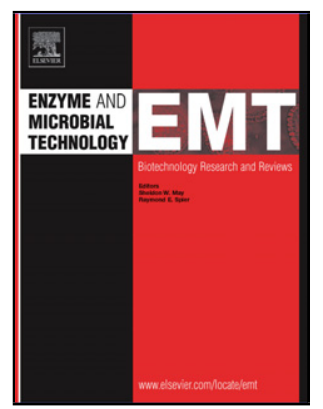
Prakash, Timothy John Hobley

PII:

DOI: S0141-0229(17)30151-5

Reference: $\quad$ EMT 9117

To appear in: $\quad$ Enzyme and Microbial Technology

Received date: $\quad$ 9-5-2017

Revised date: $\quad 1-8-2017$

Accepted date: $\quad$ 4-8-2017

Please cite this article as: Shetty Radhakrishna, Vestergaard Mike, Jessen Flemming, Hägglund Per, Knorr Verena, Koehler Peter, Prakash HS, Hobley Timothy John.Discovery, cloning and characterisation of proline specific prolyl endopeptidase, a gluten degrading thermo-stable enzyme from Sphaerobacter thermophiles.Enzyme and Microbial Technology http://dx.doi.org/10.1016/j.enzmictec.2017.08.002

This is a PDF file of an unedited manuscript that has been accepted for publication. As a service to our customers we are providing this early version of the manuscript. The manuscript will undergo copyediting, typesetting, and review of the resulting proof before it is published in its final form. Please note that during the production process errors may be discovered which could affect the content, and all legal disclaimers that apply to the journal pertain. 
Discovery, cloning and characterisation of proline specific prolyl endopeptidase, a gluten degrading thermo-stable enzyme from Sphaerobacter thermophiles

${ }^{\text {a}}$ Radhakrishna Shetty, a Mike Vestergaard, aclemming Jessen, ber Hägglund, 'Verena Knorr,

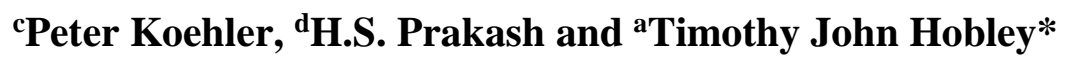

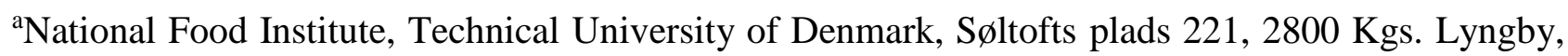
Denmark

${ }^{\mathrm{b}}$ Department of Biotechnology and Biomedicine, Technical University of Denmark, Søltofts Plads, 301, 2800 Kgs. Lyngby, Denmark

${ }^{c}$ Deutsche Forschungsanstalt für Lebensmittelchemie, Leibniz-Institut, Lise-Meitner-Str. 34, 85354 Freising, Germany

${ }^{\mathrm{d} D e p a r t m e n t}$ of studies in Biotechnology, University of Mysore, Manasagangotri, Mysore, 570 006, India

*Corresponding author

Email: tjho@food.dtu.dk, Telephone: +45 45252706

\section{Highlights}

- High temperature stable a gluten degrading

- The ability to degrade immunogenic celiac gluten peptides

- Potential of enzyme to use during mashing to produce gluten free beer

- New insights into the effects of proline specific proteases on gluten degradation. 


\begin{abstract}
Gluten free products have emerged during the last decades, as a result of a growing public concern and technological advancements allowing gluten reduction in food products. One approach is to use gluten degrading enzymes, typically at low or ambient temperatures, whereas many food production processes occur at elevated temperature. We present in this paper, the discovery, cloning and characterisation of a novel recombinant thermostable gluten degrading enzyme, a proline specific prolyl endoprotease (PEP) from Sphaerobacter thermophiles. The molecular mass of the prolyl endopeptidase was estimated to be $77 \mathrm{kDa}$ by using SDS-PAGE. Enzyme activity assays with a synthetic dipeptide Z-Gly-Pro- $p$-nitroanilide as the substrate revealed that the enzyme had optimal activity at $\mathrm{pH} 6.6$ and was most active from $\mathrm{pH} 5.0-8.0$. The optimum temperature was $63{ }^{\circ} \mathrm{C}$ and residual activity after one hour incubation at $63{ }^{\circ} \mathrm{C}$ was higher than $75 \%$. The enzyme was activated and stabilized by $\mathrm{Co}^{2+}$ and inhibited by $\mathrm{Mg}^{2+}, \mathrm{K}^{+}$and $\mathrm{Ca}^{2+}$ followed by $\mathrm{Zn}^{2+}, \mathrm{Na}^{+}, \mathrm{Mn}^{2+}$, $\mathrm{Al}^{3+}$, and $\mathrm{Cu}^{2+}$. The $K_{\mathrm{m}}$ and $k_{\text {cat }}$ values of the purified enzyme for different substrates were evaluated. The ability to degrade immunogenic gluten peptides (PQPQLPYPQPQLPY (a-gliadin) and SQQQFPQPQQPFPQQP ( $\gamma$-hordein)) was also confirmed by enzymatic assays and mass spectrometric analysis of cleavage fragments. Addition of the enzyme during small scale mashing of barley malt reduced the gluten content. The findings here demonstrate the potential of enzyme use during mashing to produce gluten free beer, and provide new insights into the effects of proline specific proteases on gluten degradation.
\end{abstract}

Key words: Allergy, enzyme, gluten, prolyl endopeptidase, mass spectrometry 


\section{Introduction}

Gluten proteins have become a very important field of research within food science, due to increasing gluten intolerance including allergy issues and public concern towards gluten. Approximately $1 \%$ of the world's population suffers with celiac disease (CD) which is an autoimmune disease caused by gluten $[1,2]$. Thus, there is growing focus in Denmark and worldwide on gluten free foods and beverages both for gluten intolerant and for the general public (normal people).Gluten is a common protein found in all cereals of the triticeae within the grassfamily where barley, wheat, rye and oats are the main industrially relevant crops [3]. These cereals contain a network of large protein molecules surrounded by starch granules and other components. When the water-soluble proteins such as albumins and globulins along with starch are washed out, the remaining water insoluble protein fractions such as the prolamin and glutenin remains and is typically called gluten [3]. Gluten is thus a prolamin and glutenin matrix present in cereals and the prolamin part e.g. gliadin in wheat; hordein in barley; secalin in rye; avenin in oat [4], can cause a deadly allergic reaction in gluten intolerant people - termed celiac disease. Oat gluten is the subject of some controversy [5], but is generally considered non-allergenic.

Celiac disease occurs in the small intestine due to the ingestion of gluten and triggers an immune response by T-cells resulting in tissue remodelling and malnutrition [6]. Earlier studies by many researchers have shown that the prolamins of gluten are the toxic agent for celiac disease, since they cannot be digested appropriately in the small intestine of humans because of their specific amino acid composition. The amount of consumed gluten is therefore crucial to celiac patients $[1,2,4]$. Gluten is rich in proline which as a unique cyclic side chain structure and imparts exceptional conformational rigidity. This distinctive structural form plays an important role in the physiological condition of different diseases by protecting immunogenic peptides from proteolytic degradation [710]. Therefore proline is present in peptides causing various diseases such as Parkinson's disease, depression, celiac sprue, annoroxia, bulimia nervosa as well as affecting blood pressure regulation. Even foods not containing whole wheat, barley, or rye often contain small amounts of prolamins from contaminations of cereals and can possibly induce allergy [11]. Gluten from these sources can be rendered safe, if it is degraded by prolyl endopeptidases into non-allergenic peptides and a number of enzyme preparations purporting to do this have come onto the market recently.

The prolyl endopeptidase (PEP), EC 3. 4. 21. 26 is also known as proline specific endoprotease and belongs to the serine protease family, has the ability to cleave peptides at internal proline residues [12]. PEP is structurally and functionally closely related to the dipeptidyl peptidase IV (EC 
3.4.14.5), oligo peptidase B (EC 3.4.21.83) and acyl-aminoacyl peptidase (EC 3.4.19.1) subfamilies are members of the S9 peptidase family. As such, this enzyme class has been extensively investigated for potential pharmaceutical use to degrade gluten or to treat celiacs and for other therapeutic use $[13,14]$.

A number of studies have examined degradation of wheat gluten and to some extent barley gluten and components by prolyl endopeptidase initially extracted from Flavobacterium meningosepticum [15] and other microbes, such as Xanthomonas sp. [16], Aermonas hydrophilic [17], Sphingoonas capsulate [18], Halobacterium halobium S9 [19], Lactobacillus helveticus [20], Myxococcus xanthus [21], Asperillus niger [22-24] and Aspergillus oryzae [25]. However, these have shown ability to break down toxic gluten peptides only under in vitro conditions. In a very recent study Janssen et al. [6] a number of dietary supplements containing different types of gluten degrading enzymes were tested for their ability to degrade immunogenic gliadin peptides from wheat. It was found that none of these enzyme preparations could degrade the allergenic peptides, except for the Aspergillus niger prolyl endopeptidase (AN-PEP) produced by DSM in Holland. In another recent article by Walter et al. [26], it was reported that the PEP from A. niger was again found to be the only enzyme capable of delivering a gluten free starch from wheat (gliadin) and barley (hordein) and had activity 690000 times greater than from bran extracts. Stenman et al. [27] also found that enzymes from germinating barley could degrade rye secalin, eliminating toxic reactions, but few, if any studies on microbial derived enzymatic degradation of secalin, or avenin appear to have been reported. Moreover, all the enzymes discussed above are limited by the $\mathrm{pH}$ and temperature range in which they are active, which makes them less suitable for the majority of industrial food processes, where high temperatures are used.

The mashing process of beer brewing (e.g. $50-80{ }^{\circ} \mathrm{C}$ ) is a crucial step for preparing the wort for the yeast fermentation. The mashing process takes approximately 2 hours and includes a series of rests at increasing temperature (typically ca. $54{ }^{\circ} \mathrm{C}, 64{ }^{\circ} \mathrm{C}$ and $78{ }^{\circ} \mathrm{C}$ ) at which the various enzymes have optimal activity; which includes $\alpha$-amylase, $\beta$-amylase, proteases, cellulases and $\beta$-glucanases. Subsequently there is a boiling step for 60 minutes at $100{ }^{\circ} \mathrm{C}$ before the wort is cooled and fermentation is initiated by yeast starter culture [28]. Beer brewing practices thus already involve protein degradation to produce fermentable amino acids for yeast growth, and it is not unthinkable to completely degrade gluten protein from beer during the mashing process itself. In fact, different methods of degrading and removing gluten have been developed, including the use of different proteases as well as microbial transglutaminase. However, no heat stable gluten degrading enzyme 
has been reported, so current efforts focus on gluten degradation during fermentation, maturation or clarification, where temperatures are typically in the sub-zero to $20^{\circ} \mathrm{C}$ range. It has been reported that gluten concentration in the final beer can be reduced by use of prolyl endopeptidase during the fermentation part of the brewing process [29]. In addition, it has been demonstrated that use of acid proline-specific endoprotease from A. niger in low level in bottled beer prevents chill-haze formation (often caused by gluten) and had almost no effect on the beer [23]. However, gluten degradation during wort preparation would be advantageous, since it would result in more fermentable amino acids in the crucial initial stages of yeast growth.

The aim of this study was to discover and characterize a novel thermostable gluten-specific prolyl endopeptidase suitable for use during the mashing step of beer production. Subsequently to express the recombinant enzyme in E.coli and to demonstrate degradation of immunogenic gluten derived peptides.

\section{Materials and Methods}

\subsection{Chemicals and reagents}

Z-Gly-Pro- $p$ NA synthetic tri-peptide substrate was used for enzyme assays (Bachem, Germany) and synthetic immunogenic celiac peptides were obtained from Genscript, USA. All other chemicals used were analytical grade which were commercially available (Sigma Aldrich, USA).

\subsection{Strains and vectors}

The strain E.coli DE3 (Invitrogen, USA) was used as host for expression. Vector pUC57 and pET$15 \mathrm{~b}$ (Gene script, USA) were used for gene manipulations.

\subsection{Cloning, culturing and expression}

Enzymes likely to be proline specific prolyl endopeptidases and with potential for high temperature and suitable $\mathrm{pH}$ tolerance properties were obtained by screening the proteome database within Uniprot for enzymes of the class EC 3.4.21.26 and filtered by bacterial taxonomy, resulting in approximately 660 un-reviewed entries. The entries were manually investigated for heat tolerant organisms, reducing the potential entries further. From the investigated entries, the Prolyl endopeptidase from Sphaerobacter thermophiles was chosen (UniProtKB - D1C7Y4). The underlying nucleotide sequence was codon optimized for E.coli expression and synthesized (Gene Script, USA). The gene was ordered sub-cloned inside the expression vector $\mathrm{pET}-15 \mathrm{~b}$, where it was flanked by an in frame N-terminal His-tag, thrombin cleavage site and a start codon. The PEP-pET$15 \mathrm{~b}$ vector was transformed into competent E.coli DE3 cells (Invitrogen, USA) and selected on 
Lysogenic Broth or Luria-Bertani medium (LB) plates containing 100 $\mu \mathrm{g} / \mathrm{mL}$ ampicillin (Amp). PEP-pET-15b cultures were grown aerobically at $37^{\circ} \mathrm{C}$ at $150 \mathrm{rpm}$ in LB $100 \mu \mathrm{g} / \mathrm{mL}$ Amp. Cultures were grown to an $\mathrm{OD}_{600}$ of 0.6 and induced with $1 \mathrm{mM}$ Isopropyl $\beta$-D-1-thiogalactopyranoside (IPTG). After 24 hours the cultures were centrifuged at $10,000 \mathrm{~g}$ for $30 \mathrm{~min}$ at $4{ }^{\circ} \mathrm{C}$ and stored at $20{ }^{\circ} \mathrm{C}$ as cell pellets until later use. For production of larger amounts of enzyme, cultivations were as described above, except using $100 \mathrm{ml}$ of medium in a $500 \mathrm{ml}$ Erlenmeyer flask.

\subsection{Purification and characterization PEP}

Cell pellets were dissolved in $10 \mathrm{mg} / \mathrm{ml}$ lysozyme (Sigma-Aldrich, USA) in a $10 \mathrm{mM} \mathrm{NaH}_{2} \mathrm{PO}_{4}$, $300 \mathrm{mM} \mathrm{NaCl}, \mathrm{pH} 8.0$ buffer and incubated at $4{ }^{\circ} \mathrm{C}$ for $30 \mathrm{~min}$ on ice. The resulting lysate was centrifuged at $10,000 \mathrm{~g}$ for $30 \mathrm{~min}$ at $4{ }^{\circ} \mathrm{C}$ and applied to a $\mathrm{Ni}^{+}-\mathrm{NTA}$ resin spin column (Qiagen, USA) under non-denaturing conditions according to the manufacturer's recommendations (Qiagen, USA). The enzyme fraction was further purified and concentrated using Amicon spin columns with $50 \mathrm{kDa}$ cut off according to manufacturer's recommendations (Amicon, USA). The different fractions during the process were retained and analysed by SDS-PAGE. The total protein concentration was determined by the Bradford method [30] using Bradford reagent (Bio-Rad, USA) and by using bovine serum albumin (Sigma-Aldrich, USA) as standard. The his-tag was also removed by treatment with thrombin, 1 units per mg (Sigma Aldrich, USA), and applied to $\mathrm{Ni}^{+}-$ NTA resin spin columns (Qiagen, USA). The enzyme fraction was further purified and concentrated using Amicon spin columns with $50 \mathrm{KD}$ cut off according to the manufacturer (Amicon, USA) as mentioned above. Both final fractions containing the desired enzyme with histag and thrombin cleaved enzyme were checked for purity by SDS-PAGE.

\subsection{SDS-PAGE analysis}

Reducing SDS-PAGE was carried out according to Laemmli et al. [30] as described previously by Studier [31]. All samples used had the same protein concentration $(1 \mathrm{~g} / \mathrm{L})$ and were mixed with Laemmli sample buffer (4x) with reducing agent (Bio-Rad, USA) and boiled for $10 \mathrm{~min}$. 20 $\mu \mathrm{L}$ were loaded per samples, while $10 \mu \mathrm{L}$ of Bench Mark ${ }^{\mathrm{TM}}$ Unstained Protein Ladder (Invitrogen, USA) were loaded for each ladder. 4-12 \% Bis-Tris (Bio-Rad, USA) gels were run at a 200V in a Trisglycine-SDS buffer (1x) (Thermo Scientific Pierce, USA). Staining was done with Instant Blue (Expedeon, USA) with slow shaking (ca. $50 \mathrm{rpm}$ ) for 1 hour, de-staining was done overnight with water.

\subsection{Determination of prolyl endopeptidase activity}


Prolyl endopeptidase enzyme activities were determined according Eden et al. [22] using the synthetic chromogenic peptide substrate benzyloxycarbonyl-glycine-proline-p-nitroanilide (Z-GlyPro- $p$ NA; Bachem, Germany), which releases nitroaniline that can be detected at $410 \mathrm{~nm}$. Z-GlyPro- $p$ NA substrate was dissolved in 1,4-dioxane (40\%, v/v in water) at $60{ }^{\circ} \mathrm{C}$ to prepare a $5 \mathrm{mM}$ solution. For the standard reaction mixture, there was $1000 \mu \mathrm{l}$ of $0.1 \mathrm{M}$ citrate/disodium phosphate buffer ( $\mathrm{pH} 7$ ), $100 \mu \mathrm{l}$ of purified enzyme, and $250 \mu \mathrm{l}$ of $5 \mathrm{mM} \mathrm{Z-Gly-Pro-pNA.} \mathrm{This} \mathrm{was} \mathrm{used} \mathrm{at}$ $60{ }^{\circ} \mathrm{C}$ unless mentioned otherwise. For determination of $\mathrm{V}_{\max }$ and $\mathrm{km}$, the standard reaction mixture and conditions were used, except the concentration of Z-Gly-Pro-pNA was varied from 1 $-10 \mathrm{mM}$. One unit of prolyl endopeptidase activity was defined as the release of $1 \mu \mathrm{mol}$ of $p$ nitroanilide per minute under assay conditions. Controls were made at the temperature and conditions under test to ensure there was no spontaneous substrate hydrolysis, by replacing the enzyme sample with distilled water.

\subsection{Characterization of $\mathrm{pH}$ and temperature dependency of the recombinant $\mathrm{PEP}$}

\subsection{1. pH optima}

To estimate the optimum $\mathrm{pH}$, purified enzyme was first incubated in $0.1 \mathrm{M}$ citrate/disodium phosphate buffer at $\mathrm{pH}$ ranging from $\mathrm{pH} 3$ to 10 at $60{ }^{\circ} \mathrm{C}$ for $30 \mathrm{~min}$. After incubation, the prolyl endopeptidase activity was measured (at $60{ }^{\circ} \mathrm{C}$ and at the $\mathrm{pH}$ being tested) at $410 \mathrm{~nm}$ spectrophotometrically using $5 \mathrm{mM}$ Z-Gly-Pro-pNA as substrate as mentioned earlier.

\subsubsection{Temperature optima}

Thermal dependence of PEP activity was determined by incubating the reaction mixture of enzyme in $0.1 \mathrm{M}$ citrate/disodium phosphate buffer at different temperatures from 20 to $80{ }^{\circ} \mathrm{C}$ for $30 \mathrm{~min}$ at $\mathrm{pH}$ 6.6. Then, the activity was determined according to the enzyme activity test at optimal $\mathrm{pH} 6.6$ and at the temperature under test (except for test temperatures of 70 and $80{ }^{\circ} \mathrm{C}$ which were measured at $64{ }^{\circ} \mathrm{C}$ due to the equipment available).

\subsubsection{Thermal stability studies}

Thermal stability assay was conducted by incubating PEP enzyme solution in $0.1 \mathrm{M}$ potassium phosphate buffer (optimal $\mathrm{pH}$ 6.6) for 5, 30, 60 and $120 \mathrm{~min}$ at different temperatures (10, 20 30, $40,50,63,70$ and $80{ }^{\circ} \mathrm{C}$ ). Then, the activity was determined as mentioned earlier at $\mathrm{pH} 6.6$ and 64 ${ }^{\circ} \mathrm{C}$.

\subsection{Enzyme kinetics PEP}


Enzyme kinetics Michaelis-Menten constant $(K \mathrm{~m})$, maximal velocity (Vmax), and $k$ cat of the purified enzyme were determined using Z-Gly-Pro-pNA with substrate concentrations in the reaction mixture of $0.2,0.5,1,1.5,2 \mathrm{mM}$ under the optimal assay conditions in the standard method, i.e. $60{ }^{\circ} \mathrm{C}$ and $\mathrm{pH}$ 6.6. An extinction coefficient for nitroaniline of $5.57 \mathrm{mM}^{-1} \mathrm{~cm}^{-1}$ at 410 $\mathrm{nm}$ was used. The reactions were conducted by adding $20 \mu \mathrm{L}$ of enzyme (containing $0.208 \mathrm{mg} / \mathrm{ml}$ protein) to buffer and substrate and the final volume was $250 \mu \mathrm{L}$ in a microtitre plate well, which equated to a $1 \mathrm{~cm}$ path length. Absorbance was measured constantly by a BioTek Synergy 2 microplate Reader (USA) after substrate addition using a Greiner Bio-One micro-titre plate. The kinetic data were calculated from Lineweaver-Burk plots using the Michaelis - Menten equation.

\subsection{Effect of metal ions on enzyme activity}

$1 \mathrm{mM}$ of each metal ion $\left(\mathrm{Mg}^{2+}, \mathrm{Ca}_{2}^{+}, \mathrm{K}^{+}, \mathrm{Cu}^{2+}, \mathrm{Zn}^{2+}, \mathrm{Na}^{+}, \mathrm{Mn}^{2+}, \mathrm{Co}^{2+}, \mathrm{Fe}^{2+}\right)$ or the inhibitors Iodoacetate $(1 \mathrm{mM}), \operatorname{PMSF}(1 \mathrm{mM})$ and $\operatorname{EDTA}(1,10,30 \mathrm{mM})$ was added to the purified enzyme solution and incubated for $30 \mathrm{~min}$ at $63{ }^{\circ} \mathrm{C}$ and $\mathrm{pH}$ 6.6. Subsequently enzyme activity was determined under the standard condition $\left(60{ }^{\circ} \mathrm{C}, \mathrm{pH}\right.$ 6.6). Enzymatic activities were expressed as relative values (\%), with enzyme not containing added ions or inhibitors serving as control (i.e. 100 $\%$ activity).

\subsection{Determination of Prolyl endopeptidase activity on gluten-specific synthetic immunogenic peptides}

The activity towards immunogenic gluten epitopes was determined as described by Gessendorfer et al. [32] using two celiac disease-active peptides PQPQLPYPQPQLPY (P1) from $\alpha$-gliadins and SQQQFPQPQQPFPQQP (P2) from $\gamma$-hordeins. Peptide solution (100 $\mu \mathrm{L}, 0.2 \mathrm{mg} / \mathrm{mL})$ and peptidases PEP $(50 \mu \mathrm{L})$ were mixed and saccharin $(10 \mu \mathrm{L} ; 0.4 \mathrm{mg} / \mathrm{mL})$ was added as an internal standard. The mixture was incubated at $50{ }^{\circ} \mathrm{C}$ and $\mathrm{pH} 6.5$ under continuous shaking in a heated thermomixer (HTML-133, HLC, Bovenden, Germany) for $90 \mathrm{~min}$. The reaction was stopped by increasing the temperature to $90{ }^{\circ} \mathrm{C}$ for $10 \mathrm{~min}$ (this is donated as the incubated sample). In the nonincubated sample, peptidases were inactivated by heating prior to incubation. Samples were centrifuged (20 min at 12,846 × $g$; Biofugepico, Heraeus, Hanau, Germany) and analyzed by RPHPLC. Samples $(40 \mu \mathrm{L})$ were separated on a Thermo Finnigan Spectra System (Thermo Fisher Scientific, Waltham, Massachusetts, USA) with Chrom Quest software using a Nucleosil C18 column (3 x $250 \mathrm{~mm}, 5 \mu \mathrm{m}, 10 \mathrm{~nm}$; Macherey-Nagel, Dueren, Germany) at room temperature. Conditions: Solvent A, $0.1 \%(\mathrm{v} / \mathrm{v})$ trifluoroacetic acid (TFA); solvent B, $0.1 \%(\mathrm{v} / \mathrm{v}) \mathrm{TFA}$ in acetonitrile; gradient, 0 - 10 min linear $0-37.5 \% \mathrm{~B}, 10-14 \mathrm{~min}$ isocratic $37.5 \% \mathrm{~B}, 14-15 \mathrm{~min}$ 
linear 37.5 - $90 \% \mathrm{~B}, 15-20 \mathrm{~min}$ isocratic $90 \% \mathrm{~B}$. The flow rate was $0.7 \mathrm{~mL} / \mathrm{min}$ and the effluent was monitored at $210 \mathrm{~nm}$. The HPLC peak areas of P1 and P2 were determined for the nonincubated and the incubated samples. The time-dependent decrease of the absorbance areas was used to calculate the peptidase activity in $\mathrm{U} / \mu \mathrm{L}$.

\subsection{Examination of cleavage pattern on synthetic immunogenic peptides}

In a second analysis for cleavage of immunogenic peptides, two of the synthetic peptides used above (i.e. PQPQLPYPQPQLPY and SQQQFPQPQQPFPQQP), as well as LGQQQPFPPQQPY were employed and were obtained from Gene script, USA. Here $20 \mathrm{mg} / \mathrm{ml}$ of the peptide under study was dissolved in water and incubated with $200 \mu \mathrm{L}$ of PEP enzyme at a temperature of $63{ }^{\circ} \mathrm{C}$ and $\mathrm{pH} 6.6$ for 3 hours. A control with peptide alone (i.e. without PEP) was also made and subject to the same assay conditions. After incubation, the reaction solution was spun through an Amicon $3 \mathrm{kDa}$ cut off columns to remove the high molecular weight enzyme. The hydrolysed synthetic peptide or the control without enzyme treatment were adjusted to a concentration of $20 \mathrm{mg} / \mathrm{ml}$ and injected into an ÄKTA purifier (PD-10, GE Healthcare) with 10 $\mathrm{kDa}$ cut off size exclusion column (Superdex 200, Amersham Biosciences). Water was used as equilibrium and elution buffer with a flow rate of $0.5 \mathrm{ml} / \mathrm{min}$ and eluents were collected in an automated fraction collector. Fractions from individual peaks were pooled and analysed by MALDI-TOF. Briefly, $1 \mu \mathrm{L}$ samples were loaded on an Anchor Chip target plate (Bruker Daltonics) followed by $1 \mu \mathrm{L}$ of $0.5 \mu \mathrm{g} / \mu \mathrm{L}$ matrix solution ( $\alpha$-cyano-4-hydroxycinnamic acid (CHCA) in $70 \%$ ACN, $0.1 \%$ trifluoro acetic acid (TFA)). Samples were analysed using an Ultra flex II MALDI-TOF/TOF mass spectrometer (Bruker Daltonics) in positive reflector mode and spectra were processed by Flex Analysis (v3.3) software provided by the instrument manufacturer.

\subsection{Effect of the PEP during mashing on gluten from malt}

To check the ability of the PEP enzyme to degrade gluten under mashing conditions, the enzyme solution (activity ca. $8.77 \pm 0.08 \mu \mathrm{mol} / \mathrm{min} / \mathrm{ml}$ ) was mixed with milled malt at a ratio of 1:1 (i.e. 4.5 g malt and $4.5 \mathrm{ml}$ of enzyme solution, plus water to give a total volume of $20 \mathrm{ml}$ ), or 1:0.5 (i.e. 4.5 g malt : $2.25 \mathrm{ml}$ enzyme plus water to give $20 \mathrm{ml}$ ) in a rapid visco analyser (RVA, Newport Scientific, Australia). Afterwards a pre-established mashing temperature profile [39], 2010) was used as follows: $54{ }^{\circ} \mathrm{C}$ and rest for $30 \mathrm{~min}$; heating up to $64^{\circ} \mathrm{C}$ and rest for $60 \mathrm{~min}$; a further heating up to $80{ }^{\circ} \mathrm{C}$ and rest for $10 \mathrm{~min}$. The wort was drained through Whatman ${ }^{\mathrm{TM}}$ grade 1 qualitative filter paper, samples were collected and total gluten content was measured using a Ridascreen R5 competitive ELISA kit (R- Biopharma, Germany) according to the manufacturer's 
instructions. Mashing with the enzyme solution replaced with an equivalent volume of water served as control. Gliadin concentrations were calculated based on a cubic spline calibration function with standards supplied with the ELISA kit and by using the RIDA_SOFT Win software (R-Biopharm, Germany). The resulting values were converted into gluten concentrations by multiplying by a factor of two (Codex Alimentarius Commission, 2008).

\section{Results and discussion}

\subsection{Cloning and expression of prolyl endopeptidase}

Given that the aim was to discover a new high temperature and $\mathrm{pH}$ tolerant prolyl endoprotease, the proteome database within Uniprot was explored for enzymes from heat tolerant bacteria. An open reading frame composed of 2064 bp, (UniProtKB - D1C7Y4) was found in Sphaerobacter thermophiles, which is a bacterium that has been reported to grow in the temperature range from 40-65 ${ }^{\circ} \mathrm{C}$ [33]. The DNA encoding this putative prolyl endopeptidase gene was then inserted into a vector behind the sequence for a poly histidine tag and thrombin cleavage site in order to facilitate subsequent isolation of the enzyme. Cells from transformed E.coli strains expressing the recombinant enzyme were harvested and the enzyme was purified from intracellular extracts by IMAC affinity spin columns. The functionality of the PEP was confirmed by its ability to hydrolyze Z-Gly-Pro- $p$ NA to release $p$-nitro aniline which was measured at $410 \mathrm{~nm}$ spectrophotometrically. The purified PEP enzyme was active both before $(8.77 \pm 0.08 \mu \mathrm{mol} / \mathrm{min} / \mathrm{ml})$ and after $(8.85 \pm 0.04$ $\mu \mathrm{mol} / \mathrm{min} / \mathrm{ml}$ cleaving with thrombin. Given there was no significant difference in activity, we omitted thrombin digestion in further work.

A reducing SDS-PAGE analysis showed over-expression of a protein of $\sim 78 \mathrm{kDa}$, which was purified to ca. $90 \%$ purity by the IMAC affinity step (Fig. 1). The histidine tag was subsequently cleaved off the PEP enzyme using thrombin which delivered a protein with a molecular weight of approximately $77 \mathrm{kDa}$ (Fig. 1). No multimers were seen. The contaminating band at ca. $14 \mathrm{kDa}$ (Fig 1) was not isolated or characterised, but probably corresponds to lysozyme (theoretically $14,3 \mathrm{kDa}$ ) added in order to disrupt the cells. The size of $77 \mathrm{kDa}$ is similar to the molecular weight of prolyl endopeptidase predicted $(76.6 \mathrm{kDa})$ (UniProtKB - D1C7Y4) from the complete genome sequence of Sphaerobacter thermophiles [34]. Previously reported prolyl endopeptidases have similar molecular weights, e.g. from Aspergillus oryzae (60 kDA), Aspergillus niger (66 $\mathrm{kDa})$, Halobacterium halobium S9 (71 kDa), Sphingomonas capsulata $(75 \mathrm{kDa})$, Pseudomonas sp. KU-22 (76 kDa), Aeromonas hydrophila (76.4 kDa), Xanthomonas sp. (75 kDa), Flavobacterium meningosepticum (76 kDa) and Human brain (79 kDa) [15-19, 23, 35-37]. 


\section{pH optima and stability}

The optimal $\mathrm{pH}$ of the PEP enzyme in terms of activity and stability was examined using Z-GlyPro- $p \mathrm{NA}$ as substrate in $0.1 \mathrm{M}$ citrate/disodium phosphate buffer $(\mathrm{pH} 3-8)$ or Tris- $\mathrm{HCl}$ (9-10). The results in figure 2 show the highest activity at $\mathrm{pH}$ 6.6. At the typical mashing $\mathrm{pH}$ of 5.6-5.8, the activity was still very high and had only declined to ca. $7.5 \mathrm{U}$ from $9.4 \mathrm{U}$. Previous studies of prolyl endopeptidases showed various $\mathrm{pH}$ optima and $\mathrm{pH}$ stability. PEP extracted from Aspergillus oryzae [35] and Aspergillus niger [23] showed maximum activity at $\mathrm{pH} 4$ and 4.2 and was stable at $\mathrm{pH}$ 3-5. On the other hand, other prolyl endopeptidases had maximum activity at alkaline $\mathrm{pH}$, for example Halobacterium halobium S9 (pH 8.7) [19], Sphingomonas capsulata (pH 8.5) [18], Pseudomonas sp. KU-22 (pH 8) [36], Xanthomonas sp. (pH 7.7) [16] and Aeromonas hydrophila (pH 7.7) [17]. Flavobacterium meningosepticum had highest activity at $\mathrm{pH} 7$ [15] and Human brain at 6.8 [37].

\subsection{Temperature optima and thermal stability of PEP}

The effect of temperature on activity was examined by incubating the enzyme at the test temperature for $30 \mathrm{~min}$ at $\mathrm{pH} 6.6$, then adding substrate and measuring activity. The PEP activity was strongly stimulated upon temperature increase and the highest activity was observed at $63{ }^{\circ} \mathrm{C}$ (Fig. 3). Importantly, high activity was seen in the temperature range $50-75^{\circ} \mathrm{C}$ (Fig. 3) where the longest time is spent during beer mashing. The PEP enzyme activity was very stable between the temperatures ranging from $50-63{ }^{\circ} \mathrm{C}$ after incubation for $30 \mathrm{~min}$. The activity decreased rapidly at temperature above $63{ }^{\circ} \mathrm{C}$. About $65 \%$ activity of the enzyme was lost when enzyme is exposed to 70 to $80{ }^{\circ} \mathrm{C}$ for $30 \mathrm{~min}$ at $\mathrm{pH} 6.6$.

To test the effect of temperature on stability of the enzyme, it was incubated at the test temperature for different times, then Z-Gly-Pro- $p$ NA was added and activity measured. The results showed that no activity was lost after $2 \mathrm{~h}$ incubation up to $30^{\circ} \mathrm{C}$. However at temperature between $40-63{ }^{\circ} \mathrm{C}, 30$ $\%$ of the PEP enzyme activity was lost upon incubation for an hour and a further $50 \%$ lost after 2 hours of incubation (Fig. 4). Whereas, at higher temperature $\left(70\right.$ and $\left.80{ }^{\circ} \mathrm{C}\right)$, the enzyme activity was completely lost, after 2 hours of incubation (Fig. 4). Comparison with the literature suggests the PEP characterised in the current work has the highest temperature optimum and stability reported so far. Previous studies of prolyl endopeptidases showed temperature optima ranging from 30-50 ${ }^{\circ} \mathrm{C}$. For example, prolyl endopeptidase from Aspergillus niger had optimal temperature of $42{ }^{\circ} \mathrm{C}$ [23], Pseudomonas sp. KU-22 was $45^{\circ} \mathrm{C}$ [36], Halobacterium halobium S9 was $40{ }^{\circ} \mathrm{C}$ [19], Sphingomonas capsulata was $43{ }^{\circ} \mathrm{C}$ [18], Flavobacterium meningosepticum was $40{ }^{\circ} \mathrm{C}$ [15], A. 
hydrophila was $30^{\circ} \mathrm{C}$ [17] and human brain PEP was $37^{\circ} \mathrm{C}$ [37]. Thermal stability studies of purified prolyl endopeptidase from Aspergillus oryzae showed it was stable up to $50{ }^{\circ} \mathrm{C}$ with a residual activity of above $70 \%$ after incubating at $\mathrm{pH} 4.0$ for $30 \mathrm{~min}$ but enzyme activity was lost above $55^{\circ} \mathrm{C}[35]$.

\subsection{Effects of metal ions and inhibitors}

It is known that some enzymes contain metal binding sites and it is possible that the PEP enzyme activity may be influenced positively or negatively by addition of metal ions and inhibitors. To test this, the enzyme along with metal ions, inhibitors or EDTA were incubated with $0.1 \mathrm{M}$ citrate/ sodium phosphate buffer for $30 \mathrm{~min}$ at $60{ }^{\circ} \mathrm{C}$ and $\mathrm{pH} 6.6$ and activities were measured using Z-GlyPro-pNA. The metal ions $\mathrm{Co}^{2+}(1 \mathrm{mM})$ and $\mathrm{Fe}^{2+}(1 \mathrm{mM})$ had almost no effect on enzyme activity ( $2 \%$ or less increase in relative enzyme activity). In contrast, $1 \mathrm{mM}$ of $\mathrm{Mg}^{2+}, \mathrm{Ca}^{2+}, \mathrm{K}^{+}, \mathrm{Cu}^{2+}, \mathrm{Zn}_{2}^{+}$, $\mathrm{Na}^{+}$and $\mathrm{Mn}^{2+}$ reduced enzyme activity approximately $10-15 \%$. The inhibitors iodoacetate $(1 \mathrm{mM})$, PMSF ( $1 \mathrm{mM}$ ), and 1 or $10 \mathrm{mM}$ EDTA had little effect on activity (i.e. ca. $4 \%$ lower), whereas 30 mM EDTA reduced activity by $10 \%$ suggesting that the PEP may require metal ions for activity, but this was not investigated further (Table. 1). Previous studies on PEP from Aspergillus oryzae and $A$. niger showed that $\mathrm{Ca}^{2+}$ ions significantly enhanced prolyl endopeptidase activity whereas, $\mathrm{Zn}^{2+}$ and $\mathrm{Mg}^{2+}$ did not have any effect; and $\mathrm{Fe}^{2+}, \mathrm{Cu}^{2+}, \mathrm{Mn}^{2}$ and $\mathrm{Al}^{3+}$ showed inhibitory effects

[23, 35]. Aspergillus oryzae prolyl endopeptidase was slightly affected (within $5 \%$ ) by $1 \mathrm{mM}$ PMSF (98 \pm 2.5 relative enzyme activity (\%)) or $1 \mathrm{mM}$ EDTA $(95.2 \pm 0.5$ relative enzyme activity (\%)) and was inhibited $(63 \%)$ by $10 \mathrm{mM}$ of EDTA $(37.3 \pm 0.5$ relative enzyme activity (\%)) [35]. Diisopropylfluorophosphate (DPF) has also been shown to inhibit a range of other PEPs [15-19, 23, 35-37].

\subsection{Determination of $V_{\max }, K_{m}$ and $K_{\text {cat }}$}

Kinetic parameters for the $S$. thermophiles PEP were determined at $\mathrm{pH} 6.6$ and $63{ }^{\circ} \mathrm{C}$ with the ZGly-Pro-pNA substrate. The results gave a good fit to the Lineweaver Burk plot (Fig. 5) allowing determination of $\mathrm{V}_{\max }$ and $\mathrm{K}_{\mathrm{m}}$ to be $3.47 \mathrm{mM} / \mathrm{s}$, and $1.5 \mathrm{mM}$ respectively, when $4.16 \mathrm{mg}$ of protein was present in the reaction solution, i.e. the specific activity is $0.834 \mathrm{mM} / \mathrm{mg} / \mathrm{s}$. Given that the molecular weight of the enzyme was found above to be $77 \mathrm{kDa}$ and assuming that it was $100 \%$ pure, then $\mathrm{k}_{\text {cat }}$ can be estimated to be $60 \mathrm{~s}^{-1}$.

\subsection{Effect of PEP on gluten content during mashing}

Total gluten content was determined following mashing with milled barley malt and the PEP 
enzyme solution (i.e. with the same activity which has been used in all the studies in the current work) added in the same ratio as the malt (1:1 ratio) or at half the volume of the malt (1:0.5). Malt without enzyme served as control. The PEP enzyme significantly reduced the gluten content by 3.35 fold (to $170 \mathrm{mg} / \mathrm{L}$ ) when used at the 1:1 ratio with malt, whereas using half as much enzyme (1:0.5 ratio) reduced gluten only by 2.24 fold (i.e. to $240 \mathrm{mg} / \mathrm{L}$ ), compare to control malt alone that had $570 \mathrm{mg} / \mathrm{L}$ gluten (Fig. 6). Wort boiled for one hour after mashing showed no further significant reduction in gluten (Fig. 6). Although the gluten was not reduced to $20 \mathrm{mg}$ gluten/kg (i.e. "gluten free") or to $100 \mathrm{mg}$ gluten/kg (i.e. "low gluten level") the results do confirm gluten degrading ability of the enzyme under the high temperature and low $\mathrm{pH}$ condition during mashing. These results are therefore consistent with earlier work by Weisner and Koehler [41] which we reviewed showing that PEP enzymes can degrade proteins as well as peptides. Therefore a large scale production of the enzyme discovered here to allow higher enzyme loadings, possibly in combination with an exopeptidase or transglutaminase should be examined in the future.

\subsection{Confirmation that the PEP degrades antigenic gluten peptides.}

We have demonstrated that the PEP discovered here has activity towards simple substrates and can degrade gluten in beer wort as demonstrated by ELISA. However, there has been discussion in the literature that even though gluten may be degraded, immunogenic peptides may remain. We therefore tested the ability of the PEP to degrade known antigenic peptides. This was first done by incubating the antigenic peptide under study for $90 \mathrm{~min}$ at $50{ }^{\circ} \mathrm{C}$ at $\mathrm{pH} 6.5$ and measuring the fragments produced. Endopeptidase was highly active toward both immunogenic gluten peptides PQPQLPYPQPQLPY and SQQQFPQPQQPFPQQP. The enzyme showed gluten-specific peptidase activities of $4.7 \pm 0.6$ Units/ $\mu \mathrm{L}$ against $\alpha$-Gliadin (p62-p75; PQPQLPYPQPQLPY) and $1.6 \pm 0.2$ Units/ $\mu \mathrm{L}$ against $\gamma$-Hordein (p48-p63; SQQQFPQPQQPFPQQP).

A peptide cleavage assay study with analysis by MALDI-TOF was also conducted to demonstrate that the enzyme cleaved at the carboxyl side of proline residues in celiac disease active peptides. The peptides from $\alpha$-Gliadin ( $\alpha 31-43)$ LGQQQPFPPQQPY, $\alpha$-Gliadin (p62-p75) PQPQLPYPQPQLPY and $\gamma$-Hordein (p48-p63) SQQQFPQPQQPFPQQP which is resistant to human digestive enzymes [38] were incubated along with PEP. Purification by FPLC and identification of these resulting fragments by MALDI-TOF (Table. 2) showed that PEP successfully cleaved these gluten peptides at the carboxyl side of proline residues. In particular at -/P-F, - /P-Q and -/P-Y peptide bonds were cleaved which resulted in peptide fragments of 1 - 13 amino acids. We are able to see fragments of 7 or above 7 amino acids with MALDI-TOF. 
Previous reports have suggested that peptides larger than 8 amino acids may still cause celiac disease, therefore further work should be done to examine the allergenic effects of different small gluten peptides, but this is outside the scope of the current work. Nevertheless, the results found here from the study on gluten degradation show that the enzyme degrades

\section{Conclusions}

The present study reveals an open reading frame composed of $2064 \mathrm{bp}$, (UniProtKB - D1C7Y4) from Sphaerobacter thermophiles encoding a gene with proline specific prolyl endopeptidase activity. When expressed in Escherichia coli and isolated, it was found to have a broad range of $\mathrm{pH}$ stability and high temperature activity and stability. The enzyme degrades the celiac-active peptides we tested, i.e. $\alpha$-gliadin LGQQQPFPPQQPY, PQPQLPYPQPQLPY and $\gamma$-hordein SQQQFPQPQQPFPQQP by cleaving at internal proline residues. It is one of the few PEP enzymes which have been confirmed to have such activity. It is thus a promising enzyme for applications where gluten degradation at high temperatures offers processing advantages, for example to degrade and reduce gluten during the high temperature mashing process of beer brewing.

\section{Conflict of interest}

The authors all declare that they have no conflict of interest.

\section{Acknowledgements}

The authors would like to thank Nina Gringer, Peter Ruhdal Jensen, Hanne Lilian StampeVilladsen, Anne Blicher and Tine Suhr for their technical support. Funding: This work was supported by the Novozymes and Henning Holck Larsen foundation. The Centre for Advanced Food Studies is acknowledged for funding the Ultraflex TOF/TOF mass spectrometer. 


\section{References}

[1] F. Koning, L. Gilisen, C. Wijmenga, Gluten: a two-edged sword. Immuno pathogenesis of celiac disease, Springer Semin Immunopathol. 27 (2005) 217-232.

[2] C. Briani, D. Samaroo, A. Alaedini, Celiac disease: From gluten to autoimmunity, Auto Immun Rev. 7 (2008) 644-650.

[3] K. Khan, G. Nygard, Gluten In: Y. H. Hui (Eds.), Bakrey Products: Science and Technology, Blackwell publishing, 2006. 97-123.

[4] M.L. Colgrave, H. Goswami, C.A. Howitt, G.J. Tanner, What is in a beer? Proteomic characterization and relative quantification of hordein (gluten) in beer, J Proteome Res. 11 (2012) 386-396.

[5] C. Ballabio, F. Uberti, S. Manferdelli, E. Vacca, G. Boggini, R. Redaelli, C. Catassi, E. Lionetti, E. Peñas, P. Restani, Molecular characterization of 36 oat varieties and in vitro assessment of their suitability for celiac diet, J Cereal Sci. 54 (2011) 110-115.

[6] G. Janssen, C. Christis, Y. Kooy-Winkelaar, L. Edens, D. Smith, P. van Veelen, F. Koning, Ineffective degradation of immunogenic gluten epitopes by currently available digestive enzyme supplements, PLoS One. 10, 2015. doi: 10.1371/journal.pone.0128065

[7] R. Mentlein, Proline residues in the maturation and degradation of peptide hormones and neuropeptides, FEBS Lett. 234 (1988) 251-256.

[8] H. Arentz-Hansen, S.N. McAdam, Ø. Molberg, B. Fleckenstein, K.E. Lundin, T.J. Jørgensen, G. Jung, P. Roepstorff, L.M. Sollid, Celiac lesion T cells recognize epitopes that cluster in regions of gliadins rich in proline residues, Gastro Enterol. 123 (2002) 803-809.

[9] L. Polgar, Structure-function of prolyl oligopeptidase and its role in neurological disorders, Curr Med Chem. 2 (2002) 251-257.

[10] L. Polgar, The prolyl oligopeptidase family, Cell Mol Life Sci. 59 (2002) 349-362.

[11] T. Thompson, A.R. Lee, T. Grace, Gluten contamination of grains, seeds, and flours in the United States: a pilot study, J Am Diet Assoc. 110 (2010) 937-940.

[12] R. Walter, W.H. Simmons, T. Yoshimoto, Proline-specific endo- and exopeptidases, Mol Cell Biochem. 30 (1980) 111-127. doi:10.1007/BF00227927

[13] D. Stepniak, L. Spaenij-Dekking, C. Mitea, M. Moester, A. de Ru, R. Baak-Pablo, V.P. van, L. Edens, F. Koning, Highly efficient gluten degradation with a newly identified prolyl endoprotease: implications for celiac disease, Am J Physiol Gastrointest Liver Physiol. 29 (2006) 621-629.

[14] C. Mitea, R. Havenaar, J.W. Drijfhout, L. Edens, L. Dekking, F. Koning, Efficient degradation of gluten by a prolyl endoprotease in a gastrointestinal model: implications for coeliac disease, Gut. 57 (2008) 25-32.

[15] T. Yoshimoto, R. Walter, D. Tsuru, Proline-specific endopeptidase from Flavobacterium, purification and properties, J Biol Chem. 10 (1980) 4786-4792.

[16] E. Szwajcer-Dey, J. Rasmussen, M. Meldal, K. Breddam, Proline-specific endopeptidases from microbial sources: isolation of an enzyme from a Xanthomonas sp., J Bacteriol. 174 (1992) 2454-2459. 
[17] A. Kanatani, T. Yoshimoto, A. Kitazono, T. Kokubo, D. Tsuru, Prolyl endopeptidase from Aeromonashydrophila: cloning, sequencing, and expression of the enzyme gene, and characterization of the expressed enzyme, J Biochem. 113 (1993) 790-796.

[18] T. Kabashima, M. Fujii, Y. Meng, K. Ito, T. Yoshimoto, Prolyl endopeptidase from Sphingomonascapsulata: isolation and characterization of the enzyme and nucleotide sequence of the gene, Arch Biochem Biophys. 358 (1998) 141-148.

[19] H. Capiralla, T. Hiroi, T. Hirokawa, S. Maeda, Purification and characterization of a hydrophobic amino acid specific endopeptidase from Halobacteriumhalobium S9 with potential, Process Biochem. 38 (2002) 571-579.

[20] V.R. Sridhar, J.E. Hughes, D.L. Welke, J.R. Broadbent, J.L. Steele. Identification of endopeptidase genes from the genomic sequence of Lactobacillus helveticus CNRZ32 and the role of these genes in hydrolysis of model bitter peptides, Appl Environ Microbiol. 71 (2005) 3025-3032.

[21] J. Gass, J. Ehren, G. Strohmeier, I. Isaacs, C. Khosla, Fermentation, purification, formulation, and pharmacological evaluation of a prolyl endopeptidase from Myxococcusxanthus: implications for celiac sprue therapy, Biotechnol Bioeng. 92 (2005) 674684.

[22] L. Edens, P. Dekker, R. van der Hoeven, F. Deen, A. de Roos, R. Floris, Extracellular prolyl endoprotease from Aspergillus niger and its use in the debittering of protein hydrolysates, $\mathrm{J}$ Agric Food Chem. 53 (2005) 7950-7957.

[23] M. Lopez, L. Edens, Effective prevention of chill-haze in beer using an acid proline-specific endoprotease from Aspergillus niger, J Agric Food Chem. 53 (2005) 7944-7949.

[24] X. Xianchang, Y. Di, L. Fuping, G. Yanlin, L. Yu, Cloning of proline-specific endoprotease gene of Aspergillus niger and expression in Pichia pastoris, J Ind Microbiol Biotechnol. 39 (2009) 7-12.

[25] H.M. Riggle, M.A. Fisher, Purification of a prolyl endopeptidase from Aspergillus oryzae and evaluation of its ability to digest gluten, Abstracts of Papers of the American $\begin{array}{lllll}\text { Chemical } & \text { Society, } & \text { vol } & 237, & \end{array}$ http://oasys2.confex.com/acs/237nm/techprogram/P1239602.HTM

[26] T. Walter, H. Wieser, P. Koehler, Degradation of gluten in wheat bran and bread drink by means of a proline-specific peptidase, J Nutr Food Sci. 4 (2014) 293.

[27] S. Stenman, K. Lindfors, J.I. Venäläinen, A. Hautala, P.T. Männistö, J.A. GarciaHorsman, A. Kaukovirta-Norja, S. Auriola, T. Mauriala, M. Mäki, K. Kaukinen, Degradation of coeliac disease-inducing rye secalin by germinating cereal enzymes: diminishing toxic effects in intestinal epithelial cells. Clin Exp Immunol. 161 (2010) 242-249.

[28] M. Gupta, N. Abu-Ghannam, E. Gallaghar, Barley for brewing: characteristic changes during malting, brewing and applications of its by-products, Compr Rev Food Sci Food Saf. 9 (2010) 318-328.

[29] C.J. Tanner, M.L. Colgrave, M.J. Blundell, H.P. Goswami, C.A. Howitt, Measuring Hordein (Gluten) in Beer - A Comparison of ELISA and Mass Spectrometry, PLos One, 2013 http://dx.doi.org/10.1371/journal.pone.0056452 
[30] U.K. Laemmli, Cleavage of structural proteins during the assembly of the head of bacteriophage T4, Nature. 227 (1970) 680-685.

[31] F. W. Studier, Analysis of bacteriphage T7 early RNAs and proteins on slab gels, J Mol Biol. 79 (1973) 237-248.

[32] B. Gessendorfer, G. Hartmann, H. Wieser, P. Koehler, Determination of celiac diseasespecific peptidase activity of germinated cereals, Eur Food Res Technol. 232 (2011) 205-209.

[33] R. Hensel, W. Demharter, R. Hilpert, The microflora involved in aerobic-thermophilic sludge stabilization, Syst Appl Microbiol. 11 (1989) 312-319.

[34] A. Pati, K. Labutti, R. Pukall, M. Nolan, T. Glavina Del Rio, H. Tice, J.F. Cheng, S. Lucas, F. Chen, A. Copeland, N. Ivanova, K. Mavromatis, N. Mikhailova, S. Pitluck, D. Bruce, L. Goodwin, M. Land, L. Hauser, Y.J. Chang, C.D. Jeffries, A. Chen, K. Palaniappan, P. Chain, T. Brettin, J. Sikorski, M. Rohde, M. Göker, J. Bristow, J.A. Eisen, V. Markowitz, P. Hugenholtz, N.C. Kyrpides, H.P. Klenk, A. Lapidus, Complete genome sequence of Sphaerobacter thermophilus type strain (S 6022), Stand Genomic Sci. 2 (2010) 49-56.

[35] C. Kang, X.W. Yu, Y. Xu, Purification and characterization of a prolyl endopeptidase isolated from Aspergillus oryzae, J Ind Microbiol Biotechnol. 41 (2014) 49-55.

[36] H. Oyama, H. Aoki, M. Amano, E. Mizuki, T. Yoshimoto, D. Tsuru, S. Murao, Purification and characterization of a prolyl endopeptidase from Pseudomonas sp. KU-22, J Ferment Bioeng. 84 (1997) 538-542.

[37] P.C. Andrews, C.D. Minth, J.E. Dixon, Immunochemical characterization of a proline endopeptidase from rat brain Its relationship to proline endopeptidase from other tissues and from other species, J Biol Chem. 257 (1982) 5861-5865.

[38] L. Shan, Ø. Molberg, I. Parrot, F. Hausch, F. Filiz, G.M. Gray, L.M. Sollid, C. Khosla, Structural basis for gluten intolerance in celiac sprue, Science. 297 (2002) 2275-2279.

[39] S. Aastrup, Beer from 100\% Barley, Scandinavian Brewers` Review. 67 (2010) 28-33.

[40] CM.M. Bradford, A rapid and sensitive method for the quantitation of microgram quantities of protein utilizing the principle of protein-dye binding, Anal Biochem. 72 (1976) 248-254.

[41] H. Wieser, Herbert, P. Koehler, Detoxification of Gluten by Means of Enzymatic Treatment, J AOAC Int. 95 (2012) 356-363. 


\section{Figures captions}

Fig. 1: Reducing SDS-PAGE of expression and purification of recombinant putative PEP from S.thermophiles. Lanes from left to right show; molecular weight marker; E.coli cell lysate before treatment; after IMAC purification; and following treatment with thrombin and subsequent removal of released tags by size exclusion. Thrombin if present would be composed of two chains at $31 \mathrm{kDa}$ and $6 \mathrm{kDa}$; lysozyme used in the lysis mixture is seen at $14.3 \mathrm{kDa}$.

Fig. 2: Activity of the putative PEP as a function of $\mathrm{pH}$ with $1.25 \mathrm{mM}$ Z-Gly-Pro-pNA as a substrate. There was $0.421 \mathrm{mg} / \mathrm{ml}$ protein in the reaction solution and it had been affinity purified by his-taged columns.

Fig. 3: Effect of temperature on the activity of the putative PEP with $1.25 \mathrm{mM}$ Z-Gly-Pro-pNA as a substrate. There was $0.421 \mathrm{mg} / \mathrm{ml}$ protein in the reaction solution. Following incubation at temperatures of $65{ }^{\circ} \mathrm{C}$ and above the activity was measured at $64{ }^{\circ} \mathrm{C}$ due to limitations in the microtitre plate system available.

Fig. 4: Effect of temperature on the stability of the PEP examined with $1.25 \mathrm{mM}$ Z-Gly-Pro-pNA as a substrate. There was $0.421 \mathrm{mg} / \mathrm{ml}$ protein in the reaction solution. Following incubation at temperatures of $65{ }^{\circ} \mathrm{C}$ and above the activity was measured at $64{ }^{\circ} \mathrm{C}$ due to limitations in the micro titre plate reader system available

Fig. 5: LineweaverBirk plot of the PEP enzyme with Z-Gly-Pro-pNA as a substrate.

Fig. 6: Total gluten content estimation by Ridascreen R5 competitive ELISA in (from left to right) wort derived from malt alone, malt treated with PEP enzyme in volume ratio of malt: enzyme of 1:0.5 and 1:1 ratio. Also another set of samples are collected after 1 hour of boiling at $100{ }^{\circ} \mathrm{C}$ mimic brewing condition. 


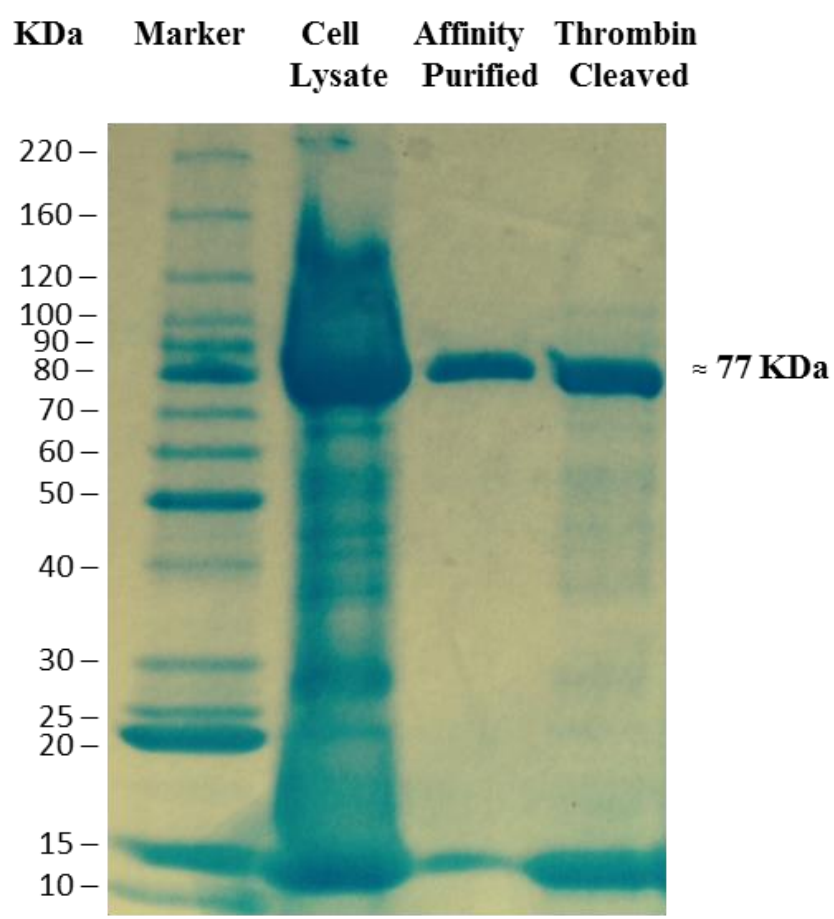

Fig. 1. 


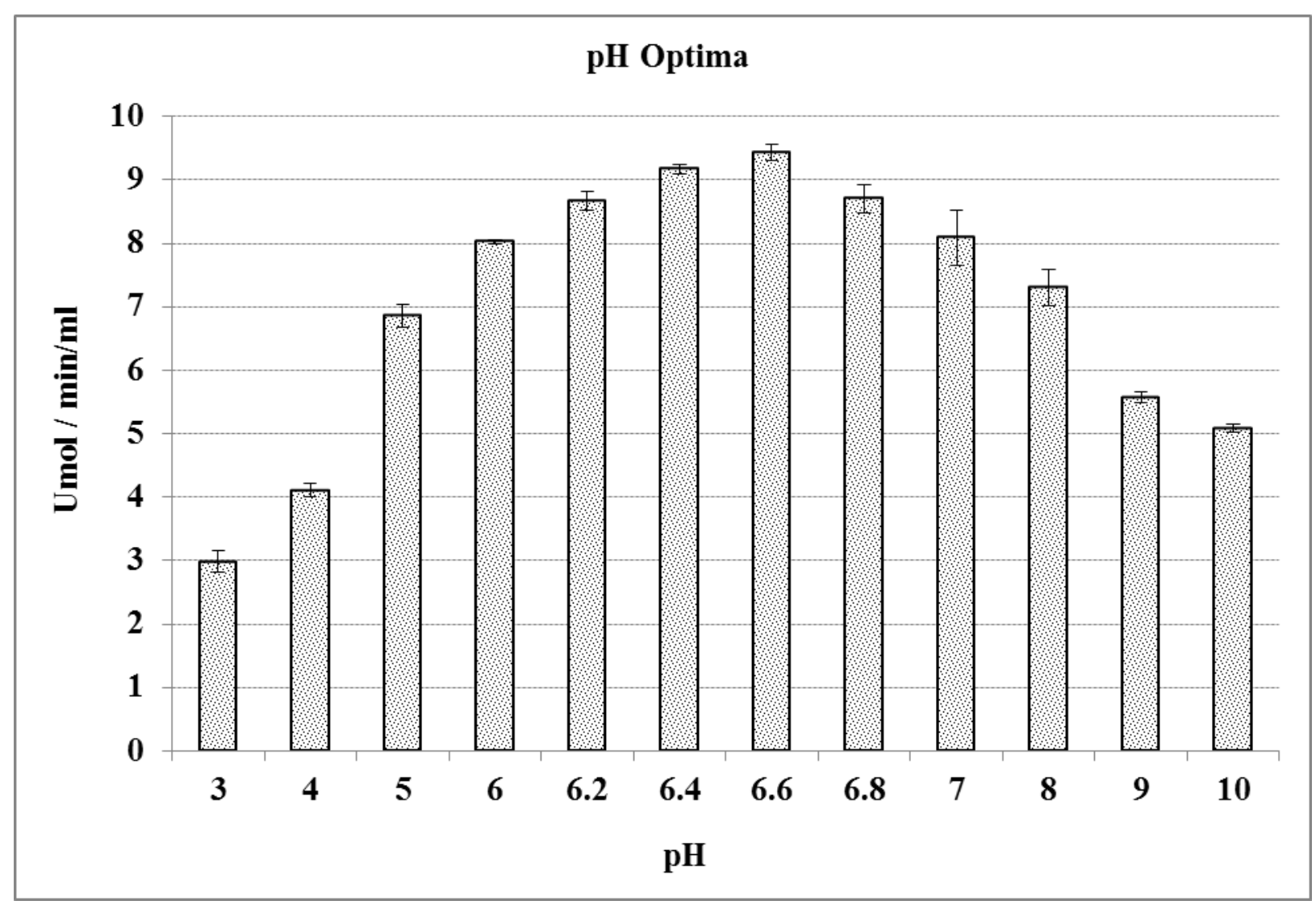

Fig. 2. 


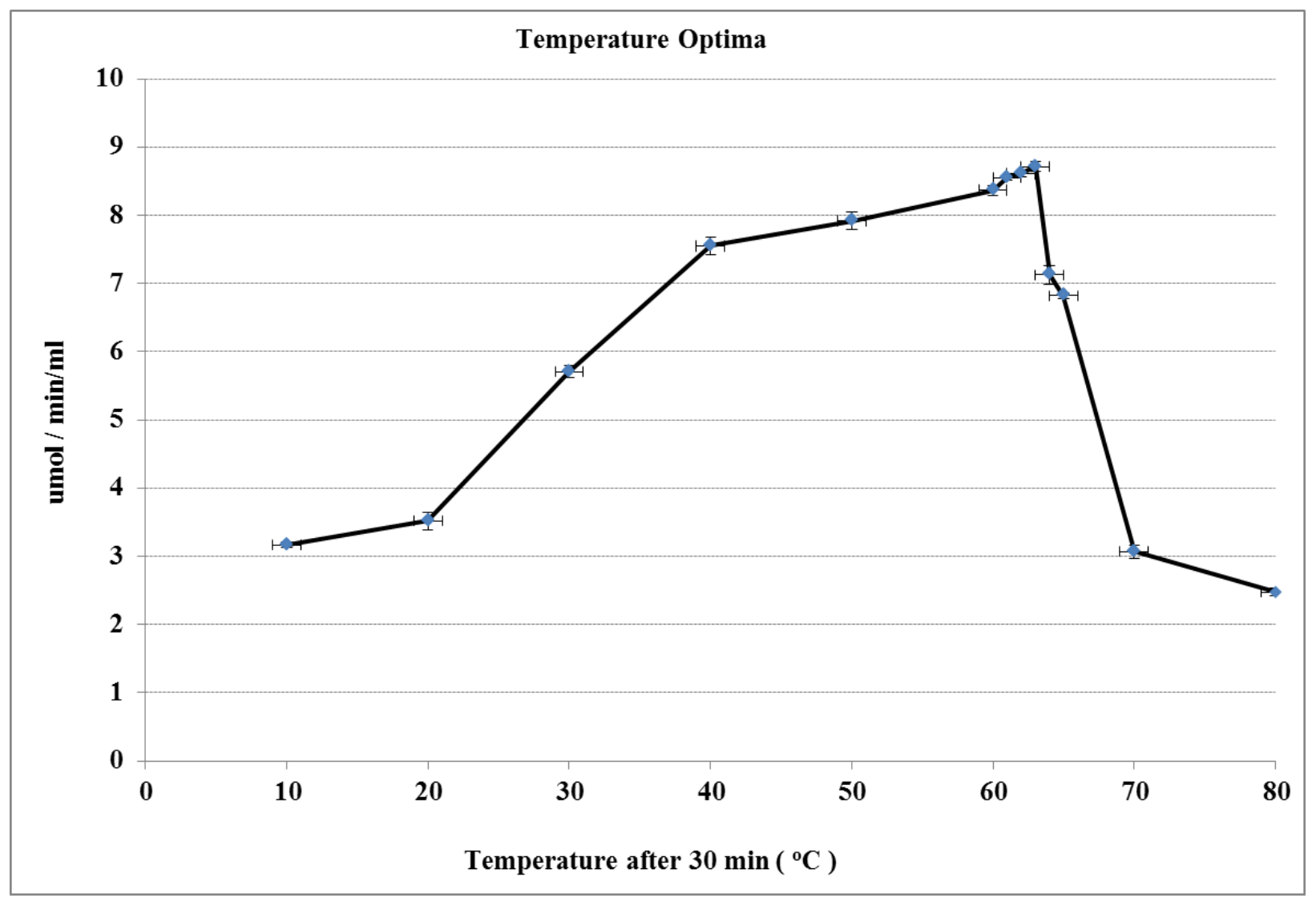

Fig. 3. 


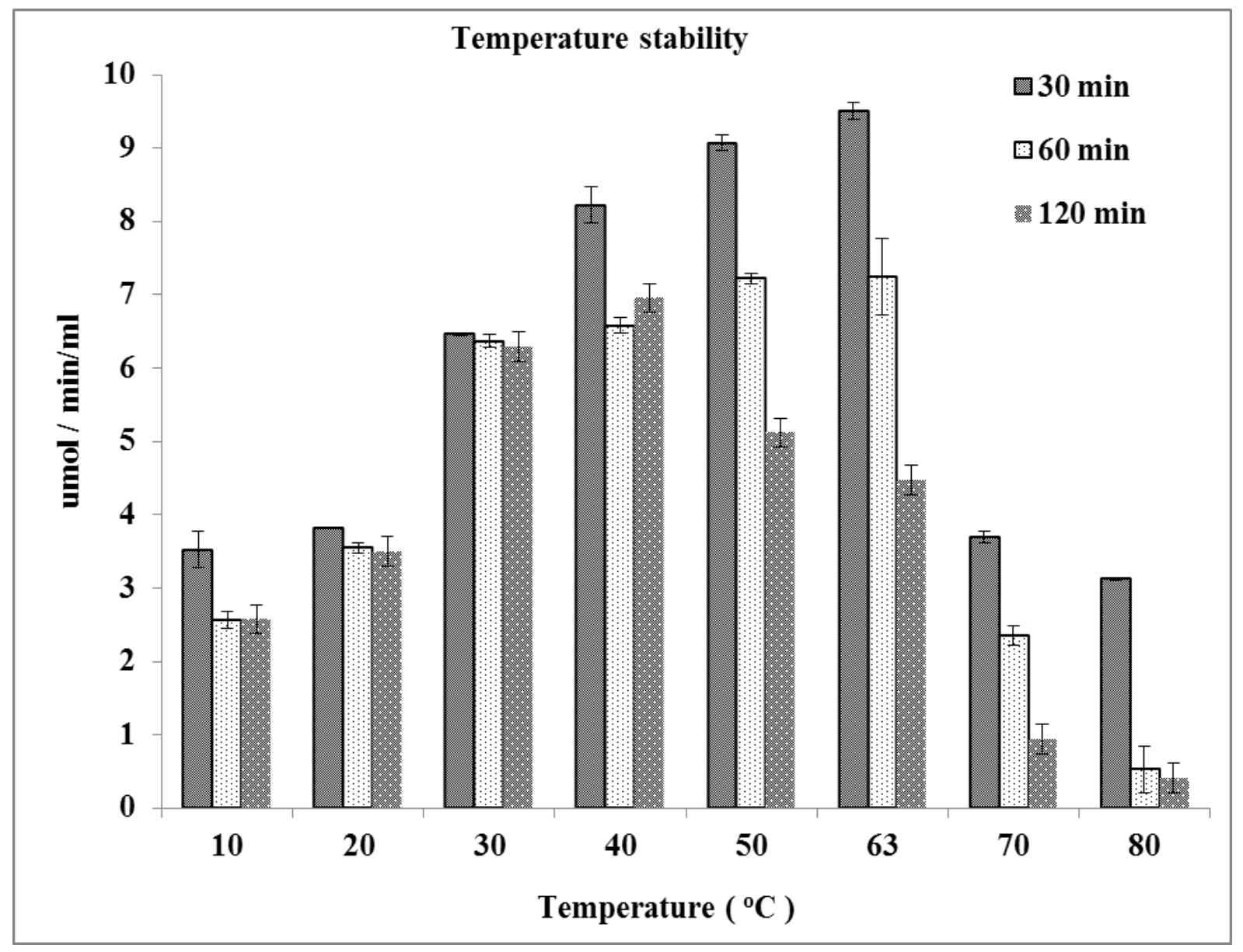

Fig. 4. 


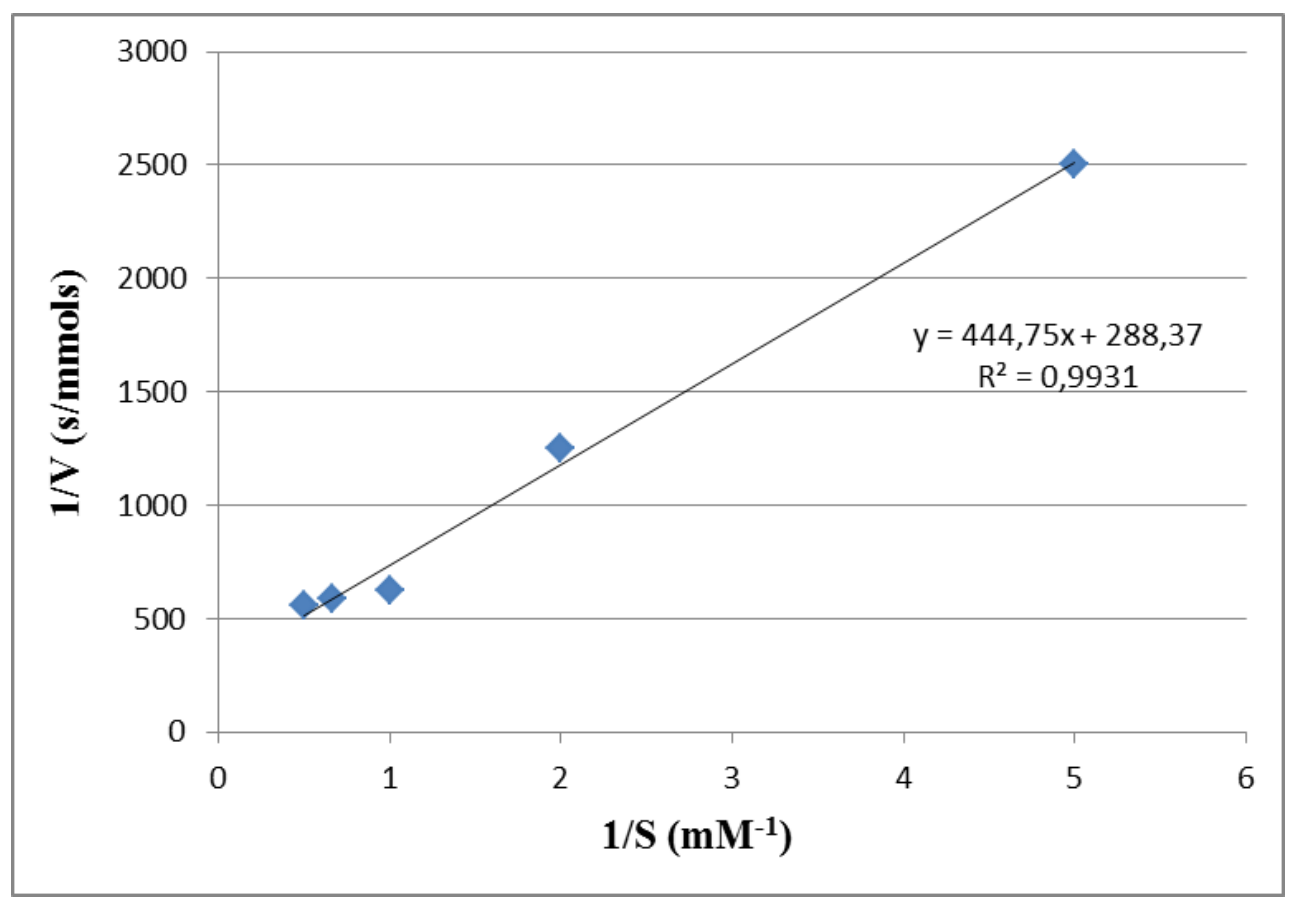

Fig. 5. 


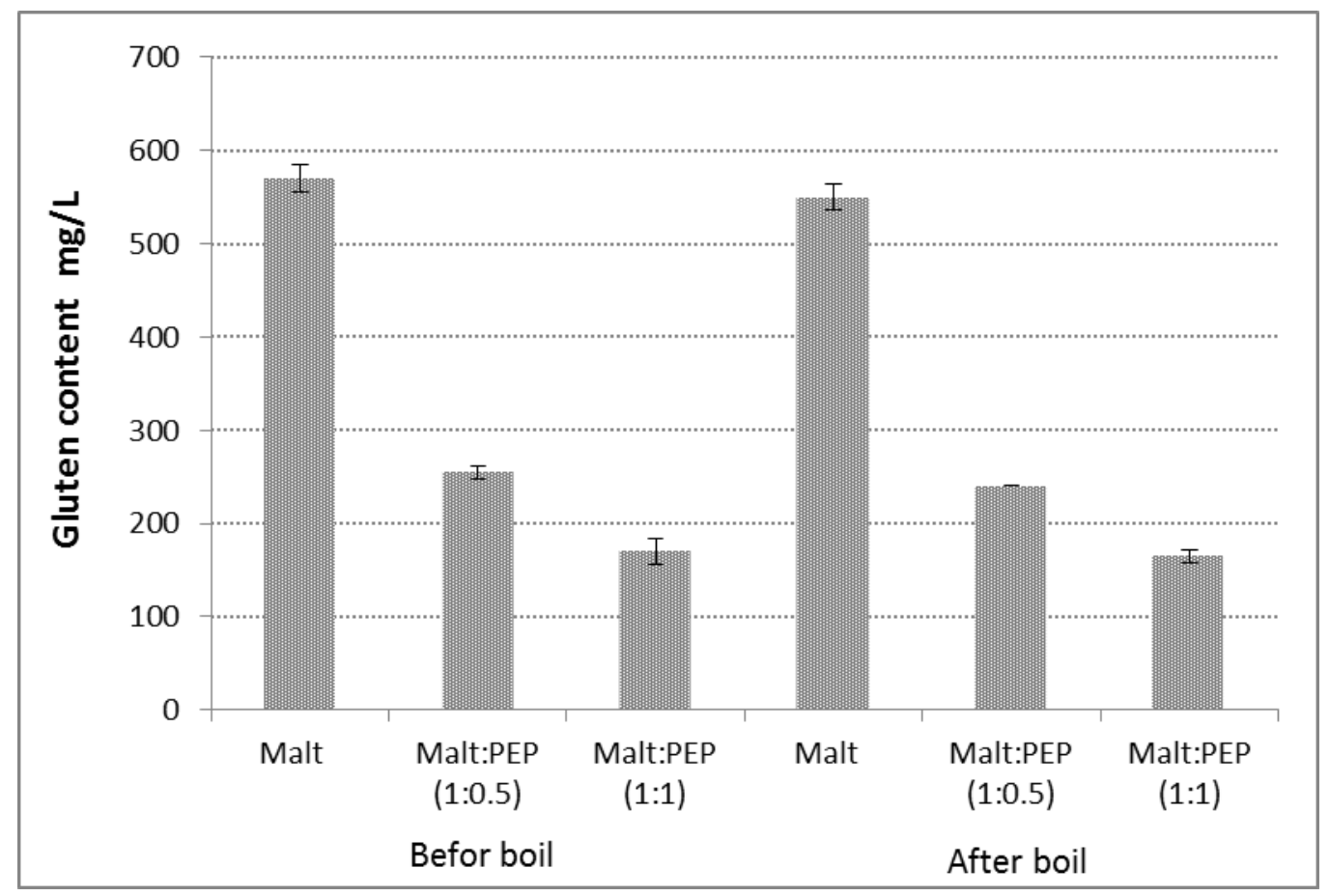

Fig. 6. 
Table 1. Effect of various metal ions on the activity of the prolyl endopeptidase from Sphaerobacter thermophiles

\begin{tabular}{lll}
\hline Metal ions and inhibitors & Concentration & Relative enzyme activity (\%) \\
\hline Enzyme & $1 \mathrm{mM}$ & 100.0 \\
$\mathrm{Mg}^{2+}$ & $1 \mathrm{mM}$ & $90.1 \pm 7.9$ \\
$\mathrm{Ca}^{2+}$ & $1 \mathrm{mM}$ & $83.9 \pm 2.1$ \\
$\mathrm{~K}^{+}$ & $1 \mathrm{mM}$ & $88.8 \pm 1.8$ \\
$\mathrm{Cu}^{2+}$ & $1 \mathrm{mM}$ & $91.2 \pm 5.1$ \\
$\mathrm{Zn}^{2+}$ & $1 \mathrm{mM}$ & $91.3 \pm 5.2$ \\
$\mathrm{Na}^{+}$ & $1 \mathrm{mM}$ & $92.3 \pm 2.2$ \\
$\mathrm{Mn}^{2+}$ & $1 \mathrm{mM}$ & $90.4 \pm 5.3$ \\
$\mathrm{Co}^{2+}$ & $1 \mathrm{mM}$ & $102.0 \pm 0.4$ \\
$\mathrm{Fe}^{3+}$ & $1 \mathrm{mM}$ & $97.3 \pm 0.9$ \\
\hline Iodoacetate & $1 \mathrm{mM}$ & $98.3 \pm 1.8$ \\
$\mathrm{PMSF}^{2+}$ & $96.0 \pm 1.3$ \\
EDTA & $1 \mathrm{mM}$ & $97.9 \pm 0.3$ \\
EDTA & $10 \mathrm{mM}$ & $95.3 \pm 4.8$ \\
EDTA & $30 \mathrm{mM}$ & $91.2 \pm 4.7$ \\
\hline
\end{tabular}


Table 2. Peptide fragments identified by MALDI-TOF after incubation with peptides LGQQQPFPPQQPY, PQPQLPYPQPQLPY and SQQQFPQPQQPFPQQP with PEP enzyme. Where P: Proline; F: Phenylalanine; Q: Glutamine; Y: Tyrosine.

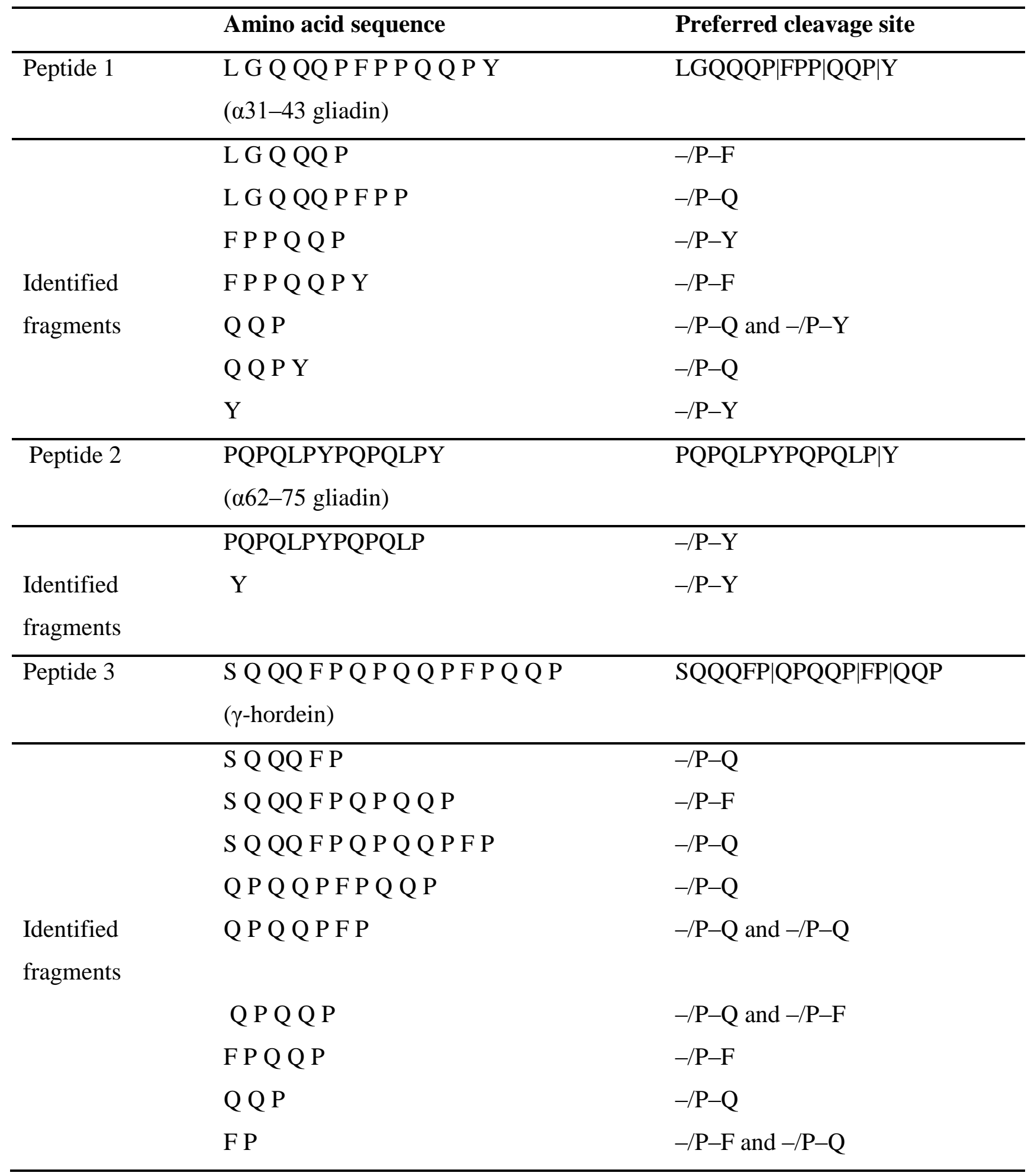

